\section{Rājarshi: The Ethical Leadership Concept of India for the World}

\section{Bidyut KUMAR SARKAR ${ }^{1}$}

${ }^{1}$ Prof. \& Managing Trustee at Prof. S K Chakraborty Memorial Trust, bidyutkumarsarkar880@gmail.com

\begin{abstract}
Humanity is precariously placed between the animality and the divinity. Modern man neither has a developed sub-mental instinct like that of the animals, nor has gained a supra-mental intuitive consciousness like that of the seers. In such a scenario, a firm leadership is required to show him the right direction. Since the collective entity like family, society, organization or nation is a summation of individuals, the effect of such leadership may be felt at these levels. Thousands of years ago, Indian Rishis discovered the laws governing the physical and moral world of human beings and applied the same to develop a leadership concept which has been in action, albeit with varying intensities, since time immemorial. Understanding that concept and its implications for the present world is an interesting endeavour.
\end{abstract}

Keywords: Values; Ethics; Holism; Emotion; Intellect; Skill; Civilisation; Culture ; Vedas; Leadership; Spirituality.

How to cite: Kumar Sarkar, B. (2020). Rājarshi: The Ethical Leadership Concept of India for the World. Journal for Ethics in Social Studies, 4(1), 99-120. https://doi.org/10.18662/jess/4.1/31 


\section{Introduction}

Transformation at the collective level presupposes a transformation at the individual level because individual is the cause, the collective is the effect. In such a scenario the leader appears to be the most important, since he/she is the cause, the originator of the process of transformation of the collective entity, be it organization, society or nation. A transformed leader can only transmit transforming influence; the inner transformation of the leader becomes the central issue. This inner transformation has been the core of spirituality and thus we infer that spirituality has to be the basis of such transforming leadership concept.

\section{Introduction to Räjarshi Concept}

Current research findings and ample indirect evidences are now available to establish that India had been an economic powerhouse for thousands of years, holding, most of the time, the highest share in the world GDP $^{1}$.

The first-hand accounts of various foreign travellers also support the same assertion; there are many other indicators and pointers to this general conclusion; accounts of economic wealth plundered by foreign invaders also indirectly point to the material richness of India. One must also consider that this wonderful richness was out of India's own efforts and was not an outcome of large scale invasion or exploitation of any other country.

This achievement on a sustained basis could not be possible without a strong leadership based on a theory which could be used to instill the right values and skills to the budding leaders. A deep introspection on the entire history of leadership in India starting from the days of the Vedic culture, Ramayana, Mahabharata to the present times shows that there has been one ideal leadership theory working all throughout the ages in India and that is $\boldsymbol{R} \overline{a j}$ arshi Leadership. This has been our parampara (tradition) ${ }^{2}$.

Thus India, from time immemorial, has been following an ideal leadership theory, in which spirituality has remained the foundation. As the name suggests, it has been a combination of two personality dimensions, the Rishi and the Rajja. The selfless seeker of the Divine Principle, living for the welfare of all, the Rishi guiding the Rajja, whose duty is to execute the laws for the welfare of the society, has been the essential characteristic of this type of leadership.

Analysis of cultural and political history of India shows that the Rajarshi Leadership Model yields two varieties at the application level: 
1. A single person showing Rajarshi characteristics ('kingly without and sagely within') in which the same person inculcates both these dimensions and his Raja dimensions are guided by his Rishi dimensions e.g. Kings Pravahana, Asvapati etc. ${ }^{3}$

2. A combination of $\mathrm{R} \bar{j} \bar{a} \bar{a}$ and Rishi as separate individual-e.g. Janaka and Yajnavalka in Brihadaranyaka Upanishad, Shivaji and Ramdas, Ashoka and Upagupta, Bukka Rao/Hari Har Rao and Vidyaranya, G D Birla \& Gandhi, etc.

In the present context-Sri Aurobindo's words become very relevant'It is the Yogin who must stand behind the political leader or manifest within him; Ramdas must be born in one body with Shivaji... ${ }^{4}$

Such a monk-monarch symbiosis may be noticed in innumerable other examples in Indian history covering all walks and sectors of her national life. The main characteristics of such leadership are -(1) more emphasis on Spirit-centred and Right-brained paradigm,(2)Transcendence and Holism,(3) reciprocal relationship between the leader and the followers but 'yatha räja, tatha prajā' (as is the leader, so are his followers) is more prominent,(4) the leader needs to be spiritualised first, the followers get spiritualized through induction,(5) lower self-guided by the higher Self ,(6) rajo guna guided by the sattwa guna,(7) sacro-secular symbiosis, (8) ethical principles are based on consciousness,(9) all social functions are rooted in the sacro-secular paradigm,(10) the main motivating factor behind the $R \bar{a} j a r s h i$ leader is the deep rooted grounding in the concept of five-fold debt model or Rin-model which leads to the Giving Model (e.g. gifts in the Aswamedha yajna of king Yudhisthira in Mahabharata, great yajna at Prayag by Harshavardhan after every five years etc.)

Kautilya, in Arthashastra, gives a list of do's and don'ts for such a leader. A brief summary of the same is given below: He should not-(i) ignore the good and favour the wicked,(ii) cause harm by new unrighteous practices,(iii) neglect the observation of proper and righteous practices,(iv) suppress dharma(principles of righteousness) and propagate adharma (unrighteousness),(v) do what ought not to be done and should not fail to do what ought to be done,(vi) fail to give what ought to be given and should not exact what he cannot rightfully take,(vi) punish those who do not deserve that,(vii) refrain from punishing those who should be punished,(viii) arrest those who should not be arrested and should not fail to arrest those who should be seized,(ix) indulge in wasteful expenditure,(x)destroy profitable undertakings,(xi) fail to protect the people from thieves,(xii) rob them himself,(xiii) cause harm to the leaders of the people and should not 
insult those worthy of honour,(xiv) antagonize the wise leaders by lying and mischief,(xv)recompose service done to him,(xvi) destroy the welfare of his people by his indulgence and negligence,(xvii) commit adultery or covet others' wealth ${ }^{5}$.Thus he shall not act in such a manner as would cause impoverishment, greed or disaffection among the people ${ }^{6}$. On the other hand, he should -(i) exercise self-control, having conquered (the inimical temptations of the senses,(ii) cultivate the intellect by association with elders,(iii) be ever active in promoting the security and welfare of the people,(iv) ensure the observance of their dharma( principles as per their social life-stages) by authority and example,(v) improve his own discipline by continuing his learning in all branches of knowledge,(vi) endear himself to his people by enriching them and doing good to them,(vii) practice ahimsa(non-injury) to others,(viii)avoid day-dreaming, capriciousness, falsehood and extravagance,(ix) avoid association with harmful persons and activities, (x) maintain a balance of four life goals (purushärtha(s) viz. dharma, artha, käma, moksha) in his life ${ }^{7}$.

\section{Values, Ethics, Skill and Holism}

Now let us address the question-What are Values? Whom do we approach to get an answer? Einstein, arguably the greatest scientist of the last century, says-'a positive aspiration and effort for an ethical-moral configuration of our common life is of overriding importance. Here no science can save us. ${ }^{, 8} \quad$ Then who can save us? We classify the learned people into four basic categories-1) Researchers 2) Scholars 3) Thinkers and 4) Realizers - there are levels higher than this but in the present context we stop here. For our purpose we generally refer to the thinkers and realizers.

Let us introduce the idea with a small illustration-Doctor 1(D1)keeping a dead patient in the ICU to squeeze more money from patient's family, Doctor 2(D2)-giving free treatment once a week... What made these two doctors behave the way they did? D1-greed, D2-kindness. Now let us convince ourselves-greed, kindness etc. all are emotions emanating from the psychological heart and not intellect related to the brain. So we come to one very important conclusion-Emotion is the driver of our personality, not intellect. To clear any doubt, let us listen to some great thinkers-Einstein says -'Intellect cannot lead, it can only serve...It is blind to ends and values." Again, Swami Vivekananda opines- 'It is the heart that takes one to the highest plane, which intellect can never reach ${ }^{10}$.Mahatma Gandhi is more poignant-- '... "I know that ultimately one is guided not by the 
intellect but by the heart. The heart accepts a conclusion for which the intellect subsequently finds the reasoning. Argument follows conviction. Man often finds reason in support of whatever he does or wants to do."...11

These enduring emotions or hridaybritti(s) in a person which make him choose his goals as well as means to achieve them are called Values. Enduring emotion implies most predominant and often occurring emotion of a man e.g. for a short-tempered person, anger is the predominant emotion.

By now we have probably noticed that these emotions are of two types-positive and negative. The positive emotions (really beneficial to the person as well as to the society) are called Human Values and negative ones (harmful to the person as well as to the society) are called Dis-Values. Intellect or Buddhi-vritti serves the emotions, itself being values-neutral. So D1 was driven by Dis-Values and D2 was acting under the influence of Human Values.

Now we will come to the other most important concept i.e. skillswhich are the external methods and techniques to perform any task. Both D1 and D2 are highly skilled doctors-D1 being a renowned heart surgeon and D2 being a gynaecologist. So skills and values are the two dimensions of human personality (like the two wings of a bird). Both these parameters can be of two types-high and low (low values imply disvalues). Thus we may have four combinations viz. High Values, Low Skills; High Values, High Skills; Low Values, High Skills; \& Low Values, Low Skills; which may be depicted in a 2D diagram having four quadrants. This is a very effective and simple tool to classify oneself and others in an organization or society and take effective interventions. Please note values, as we have presented here, are universal and perennial whereas skills are domain specific and therefore dependent on space and time. The person having high values and high skills is said to have holistic personality.

Now we need to introduce the concept of Ethics. Ethics may be defined as the external expressions of values within i.e. Values are the cause, Ethics the effect .In our previous illustration, D1 driven by DisValues and high skills resorted to unethical activities, D2 on the other hand inspired by Human Values and high skills displayed ethicality. Thus we find people in High Skill, Low Values quadrant will be most prone to be unethical. Too much emphasis on skill development which is required to make them job-ready but too less on values has resulted in more people moving to this quadrant. Hence so much of values-crisis, unethicality, scams etc. 


\section{Rajjarshi - The Values and Ethics Oriented Leadership}

Since manifestation of Rajjarshi dimensions is essentially an outcome of the development of such values, Rajjarshi leadership may be termed as a values based leadership concept. Moreover, since development of human values primarily depends upon restraining the dis-values, the whole thing ultimately boils down to purification of emotions or Chittashuddhi. Thus anyone who aspires to be a Rajarshi leader has to go through a strict regime of any one or more methods leading to Chaittashuddhi.

All the great thinkers of India, writing on leadership, have stressed upon restraining the dis-values and striving for Chittashuddhi e.g.

- Kautilya, the famous author on Arthashastra, says

0 'Hence by overthrowing the aggregate of the six enemies, he shall restrain the organs of sense;... keep up his personal discipline by receiving lessons in the sciences;'

- 'Thus with his organs of sense under his control, he shall keep away from hurting the women and property of others; avoid not only lustfulness, even in dream, but also falsehood, haughtiness, and evil proclivities;'

- 'Not violating righteousness and economy, he shall enjoy his desires. He shall never be devoid of happiness.... ${ }^{12}$

- Hence, Kautilya endorses that one who becomes a good leader should develop himself first. If he can control all desires then only he can guide his followers to do the same. Swaràt samrät bhavati (he who can govern himself, alone can govern others) should be the guiding principle of a Rajjarshi Leader, which means that a leader should first control his own character and be able to guide himself in the right path then only he can guide his subordinates.

- Manu, the great ancient law-giver also argues in similar line. In Manusmriti a king is compared to the gods. The king according to the laws of Manu was formed of particles of gods, so he surpasses all created beings in lustre. He is compared to the Sun, the Moon, Yama (the lord of justice), Kubera, Varuna and the great Indra ${ }^{13}$. The duties of a king are elaborated in Chapter VII verses - 35-40. A king has been created to be the protector of social stratification (varna) and order. The king after rising early in the morning, worships Brahmanas who are well versed in the threefold sacred science, the Vedas, and follow their advice ${ }^{14}$. Thus a ruler should always be 
guided by a learned and wise Rishi-like personality. A blend of royalty with sacredness is also confirmed here.

The sage and the ruler in combination formed the ideal model of Rajjarshi Leadership concept. In Chapter VII verses- 41-52, the qualities of a good king are enlisted. A good king should have qualities like modesty, humility, self- control (control of one's senses) etc. The king should avoid vices like hunting, gambling, sleeping by day, censoriousness, drunkenness, inordinate love for dancing and singing, useless travel etc. ${ }^{15}$

Thus Manusmriti elaborately discusses on the attributes of kingship that forms an image of ideal Rajjarshi leader. The attainment of these attributes again depends on the extent of purification of emotions or Chittashuddhi.

\section{Rājarshí: The Perennial Leadership Theory of India}

If we scan the sacro-secular historical literature of India, we find illustrations of Rajjarshi in action right from the Vedic period.

Ramayana: The whole Ramayana is based on the Rajarshi concept. The central character, Sri Rama, was the epitome of the principles that uphold the universe (i.e. dharma) and hence an ideal Rajarshi and according to many sädhaka(s) (spiritual aspirants) much beyond that, the Incarnation of the Godhead himself. Here we take Bharata, his able brother, as an illustration. Bharata, as depicted by sage Valmiki, in Ramayana, showed both Raja and Rishi dimensions e.g. he was well versed in both the shästras (scriptures) as well as in the subject of warfare; he had pure character and untainted intelligence ${ }^{16}$; he was righteous, truthful and noble ${ }^{17}$; he didn't want to be the king at the behest of the game-plan hatched by her unscrupulous mother, rather he wanted his elder brother to be the king and himself wanted to go for 14 year exile in the forest to keep the words of his deceased father-this shows his righteousness and sense of renunciation; When Sri Rama refused to come back from exile, Bharata ruled the kingdom as a trustee for 14 years, while himself staying outside the capital at Nandigram and living like a forest dwelling Brahmachāir (celibate) ${ }^{18}$, considering Sri Rama as the real ruler, being represented by his pädukè (s)(footwear) - all these show his astounding humility, renunciation and love for truth. At the same time, he increased the wealth by ten times in this time - this shows his great Rajja characteristics-he was an ideal brother and king who executed his duty remaining ever respectful towards the elders and 
sages. Thus he was following the essence of Rajjarshi leadership. Such leadership characteristics are found in most of the other kings in his dynasty e.g. in the Raghuvamsam, the famous literary classic by the great poet Kalidasa, we find mention of as many as twenty-eight kings who had followed the above dimensions to a large extent and were guided by able spiritual giants as their guru(s) or preceptors.

Mahabharata, 'the huge encyclopaedia of knowledge and wisdom', 'the greatest compendium ever composed...the national university of India ${ }^{19}$, has the depiction of characters of all hues and characteristics. Let us take special note of one very prominent character, Yudhisthira, who was chosen by the Lord to be the Räj Chakravarti (the King of Kings) of Bharatvarsha (i.e. India) because of his stellar characteristics. From his childhood, he was calm, composed, reserved, very intelligent, soft-spoken, truthful, honest and at the same timer had the elegance of a lion in his physique and movements. He was well-versed in the Vedas, Upanishads, Vedānga (s) and Nitishastra(s)(Ethics) ${ }^{20}$.In a short span of time, he with the help of his very able brothers, the pandavas, and others built an attractive city at Indraprastha and administered it with great dexterity and righteousness for twenty-three years. During this period, among other great qualities, his affinity to seek advice from elders, learned and wise people, may be specially mentioned-it shows his humility and love for knowledge and wisdom ${ }^{21}$.His delegation of authority and responsibility attracted great appreciation and displayed his managerial skill. His Rishi qualities were of great help for his brothers e.g. during the initial period of 12 year exile, Rishi Vyasa (the great composer of Mahabharata) chose him to be the upholder of the pratismriti vidya (a special mantra or spiritual formula) which he imbibed with all humility and wisdom and later made Arjuna, his very illustrious brother, well versed in it; Arjuna utilized it later to get the divine weapons from the gods which made him invincible ${ }^{22}$;Yudhisthira saved the lives of his brothers many times because of his deep knowledge, wisdom and sagacity e.g. he saved Bhima from the clutches of Nahusha, again he saved all his four brothers by giving correct answers to more than hundred questions of Yaksha. All these episodes display his illumined intelligence-a Rishi dimension. At the onset of the Kurukshetra war, he did not forget to show humble respect to his elders, who were arrayed against him in the war-leaving his kabaj (armour) and weapons, he walked with folded hands towards his adversaries and paid respect to his venerable elders like Bhisma, Drona, Kripa and Shalya and sought their blessings and permission for the war-this great gesture of goodwill was highly lauded ${ }^{23}$.After the 18 day war 
was over, when Bhisma was lying on the bed of arrows, waiting for the auspicious moment when he would leave his mortal frame, at the advice of Srikrishna, he learnt the great lessons on public administration(Rajadharma) from Bhisma, with deep reverence and humility, for 30days(which comprises most of the huge Shantiparva and part of Anushasan parva) - thereafter he ruled the nation for 36 years as an embodiment of renunciation and righteousness. He has been praised as 'dharmaraj'(the most righteous) by Srikrishna himself, 'dharmamaya mahäriksha'(the great tree of righteousness) by Vyasadeva,Rajarshi by the famous and dreaded sage Durvasa, Maharshilike Räjarshi by Arjuna ${ }^{24}$.

Upanishads, the gyankanda (the knowledge portion) of the Vedas, essentially express the blissful beauty of the Highest Reality, that interpenetrates and transcends all sense-perceived entities, the Brahman, the Sat-Chit-Ananda (The Existence Absolute, the Consciousness Absolute, the Bliss Absolute), the OM (the primordial sound), the First Cause and the Ultimate Refuge of all existence ${ }^{25}$. The Raja and the Rishi dimensions are inherent in the manifestations of and dissolution in this Ultimate Reality. Realising this divine play by being one with That is the aim of Upanishadic spirituality. From the high altitude, flows the stream of life, down to our mundane level of duality e.g. life and death, happiness and sorrow, enmity and friendship, light and darkness, hot and cold etc. Experiencing the state of nirdwanda (a state of mind beyond all kinds of duality) through samattwa (a mental state of equanimity) one can reach the pinnacle of this spirituality. We find mention of many such glorious personalities, who displayed the Rajarshi characteristics, in the principal Upanishads esp. in Chandogya and Brihad Aranyaka Upanishads. King Asvapati, the son of Kekaya and Pravahana Jaivali ${ }^{26}$ are two prominent characters in Chandogya Upanishad who had realized such heights. Similarly, in Brihad Aranyaka, we find Ajatashatru, king of Kashi (Varanasi) teaching a Brahmin about the depth of such experiences; we also find the great women Rishi(s) like Maitreyi and Gargi ${ }^{27}$ participating in very erudite and lofty discourses regarding the subject as also king Janaka displaying the aspirations to attain the Rishihood in his discussion with Sage Yajnavalka.

In the huge body of literature known as Puranas we find many characters displaying the essence of Rajarshi Leadership. In fact, the leaders, who have been hailed as the greatest and the noblest have all displayed such characteristics to varying degrees. For instance, in the popular SriSri Chandi of Markendeya Purana, we find king Suratha, having lost his kingdom to 
the traitors, took refuge in the sage Medhas, at his ashrama and under his spiritual guidance regained the strength to get back the lost kingdom-this gross-level incident may have profound implications for the sädhaka (spiritual aspirant) when seen from a subtle level for which it has been revered with highest devotion.

\section{Rajarshi Leaders in Recent History}

Thus we notice, discovering the divine within (Rishi dimension) and manifesting it without (Räja dimension) has remained the hallmark of Indian civilization. This noble trend we find among our great kings and rulers of all ages e.g. Chandragupta Maurya (340BC - 297BC?) founder of the Maurya Empire, built one of the largest empires in the India subcontinent, under the able guidance of Chanakya (or Kautilya) —a Rajarshi combination. Their achievements in the form of economic prosperity, infrastructure, army, religious harmony etc. are well documented. He was regarded by many as 'the best of kings' ${ }^{28}$. Such achievements are the result of the monkmonarch symbiosis, typical of India's tradition. If we investigate the factors contributing to such glorious outcome we find the Rajjarshi process in actiondetailed exposition of the philosophy behind such action may be obtained in the Kautilya's Arthashastra, particularly the section in which Chanakya is explaining the training of the prince. It was under great discipline of selfgovernance and self-restraint that such emperor could develop-one is convinced of such discipline if one goes through the rigorous 24 hour routine suggested by Chanakya for the king. 'Only such a disciplined king gains true knowledge, becomes wise, and treats justly all his people...The greatest asset and reward of such a Rajarshi is the loyalty and trust of his people. These ideals constitute the perennial nucleus of Bharat's conception about leadership in all spheres. ${ }^{29}$

His grand-son, Emperor Ashoka (304-232 BC), reached the zenith, through the transformation of Chandashoka (Ashok, the terrible) to Dharmäshoka (Ashoka, the righteous)—this metamorphosis again happened under the mentorship of Upagupta, a highly venerable monk. The Rajjarshi process had profound impact in him and its manifestation was lauded by international historians e.g. Vincent Smith observed-'...he managed to reconcile the apparently inconsistent positions of monk and monarch...he was wonderfully successful in holding together for forty years an empire rarely exceeded in magnitude. ${ }^{30}$ The touch of Divine within has manifested in his efforts without to elevate the moral life of his subjects 'by a growth in piety' from which he published 'precepts of piety', organized 'edifying 
spectacles representing things Divine', popularized pious tours, abandoned hunting games and similar royal amusements, '..military pageants and secular shows'; 'himself went on pilgrimage to Bodhgaya, Lumbini etc., flesh eating was gradually eliminated in the royal household, govt. officials called Dharma Mahamatras were appointed to spread the dharma', 'emissaries for this goal to other countries' were sent. ${ }^{31}$ Thus behind this mammoth task spanning across the length and breadth of his huge empire and beyond, driven by the Räjä dimensions was inspired by the Rishi dimensions within. Thus we find the same parampara (tradition) of Rajjarshi leadership working through these great personalities.

The strong Räjarshi vibrations initiated through the Arthashastra of Chanakya $^{32}$ and its practical application in the form of Chandragupta Maurya and their culmination in the form of great Emperor Ashoka, kept reverberating in later periods of Indian history and gave rise to kings and emperors of such hues from time to time. One such prominent example after few hundred years of Ashoka is the elected king Harshavardhan (590-647 AD?).He was a classic embodiment of considerable Raja and Rishi dimensions fused into one personality which is evident from the following comments of the great contemporary historian R K Mukherjee-'... a supremely versatile genius and complex character. He was at once a prince and a poet, a warrior and a man of letters, royal and kindly, with unbounded wealth given away in unbounded liberality, with the dignity of a paramount sovereign joined to the humility of a beggar, master of all the military as well as the fine arts, of all knowledge and virtues. ${ }^{33}$ His reign(c606 -c647 AD) was marked by peace, prosperity, erudition, learning and cosmopolitanism which attracted scholars and visitors from across the world of which the most famous has been the Chinese traveller Xuanzang (or Hieun Tsang) whose favourable account of his rule marked by justice and generosity is well known. Typical of Raja characteristics of renunciation, Harshavardhan was an epitome of regal renunciation, esp. his great religious ritual (mabā yajna) after every 5 years which extended for a period of two months at Prayag, in which he gave away costliest gifts to people of all social stages till he reduced himself to almost a pauper, has remained a glorious illustration of true dānam (charity) that is again an ancient legacy (let us remind ourselves the great danam of king Yudhisthira in Mahabharata or Raghu in Raghuvamsam of Kalidasa $^{34}$ so fervently prescribed and eulogised in our scriptures).

Many a time such luminaries of Rajjarshi characteristics arose in the arena of Indian leadership and generated noble vibrations throughout the 
nation which could be felt for centuries. Another great scholar of our contemporary times, Benoy Kumar Sarkar, thus points out that such vibrations set out by King Harshavardhan influenced the later kingdoms of the Palas, Senas, Rashtrakutas, Cholas etc., so much so that he christened them as the 'spiritual successors' of Harshavardhan. ${ }^{35}$

Another instance of a Rishi-like personality guiding a potential raja to manifest a great leadership, leading to strong and prosperous kingdom is that of Sage Vidyaranya of Shringeri mentoring brothers Harihar and Bukka Rao to establish the famous South Indian kingdom of Vijaynagar in $14^{\text {th }}$ century $\mathrm{AD}^{36}$. From various inscriptions in Kannada we learn that Harihar Rao was a master of great knowledge and skills and that his love of learning is also brought out by the fact that he named his capital as Vidya Nagar (the city of learning). At the same time he was an able administrator and an empire builder whose empire stood the test of time for few hundred years. Thus the Vidyaranya-Harhar Rao and Bukka Rao combination may be thought of also as the legacy of the same Rajarshi parampara or reenactment of the Chanakya-Chandragupta,Upagupta-Ashoka mode of leadership. ${ }^{37}$

Shivaji Maharaj, the great Maratha king of $17^{\text {th }}$ century, a symbol of valour and renunciation, courage and humility, egalitarianism and kindness, displayed the characteristics of Rajarshi leadership substantially. Like most of the other such leaders in India from time immemorial, he was interested in religious teachings and enjoyed the company of saints and sages ${ }^{38}$. His love and respect for the Rishi dimensions have been immortalized by the Rishipoet of our times, Rabindranath Tagore through his poem Pratinidhi (the Representative):- the inspiring poem is based on the account of an encounter between king Shivaji and his Guru Ramdas-' Once Shivaji spotted his guru begging on the streets of the capital. The tormented King kneeled down, offered his crown and all else at the feet of his Guru. He accepted all of this. But, in return, bid Shivaji to rule the land as a renunciant and servant on his behalf... Thereafter Ramdas conferred the gerua robe of a sannyasi to Shivaji...' The Guru said (as the poem goes)-'Be the Regent of a beggar that is me/Be the lord of the land, yet poor and unattached...Hold the kingdom, yet be not a king... ${ }^{39}$ - this has been the essence of the Räjarshi concept of India—renunciation and service.

Devi Ahalyabai, the famous queen of Maratha dynasty of late $18^{\text {th }}$ century, known for her philanthropic activities across India and her enlightened administration is another example of the Rajä dimensions being guided by the Rishi. She was known for her piety and strong character right 
from her childhood. Her administration, characterized by perfect order, good government, peace and prosperity, kindness and sensibility, generosity and nobility had been praised by the great thinkers of India and abroad. The effect of her illustrious and long list of works across the nation can still be observed and felt. When we deeply investigate and ponder upon the source of strength of such leaders, we are again convinced of the efficacy of the Rajarshi model. She earned respect from one and all and is still considered a saint by the people out of deep gratitude.

Rani Rashmoni, the venerable harbinger of the Spiritual Light in the $19^{\text {th }}$ century, very pious from childhood, led religious and austere life, took charge of zamindari and finances after her husband's death when she was 43, known for her kindness, courage, righteousness, able administration and philanthropic activities. Her contribution in the establishment of National Library and Hindu College (now Presidency University) in Kolkata are well known, She is mostly remembered for her establishing the Dakshineshwar Temple which later became the Lila-Kshetra (the field of divine sport) of Thakur Sri Ramakrishna Dev along with Swami Vivekananda and many of his illustrious renunciant and householder disciples. Her charitable works are well known, she is still respected for her divine and spiritual nature and gratefully remembered for her great contribution in the rejuvenation and spiritual awakening of the people of India whose seeds were sown by her through the establishment of the Dakshineswar Temple.

The essence of the Rajjarshi characteristics as the backbone of the leadership in India was not confined within the kings and queens only. It may be traced in the other corporatized groups and legally constituted bodies in ancient and medieval India. Apart from these non-religious institutions, the religious corporations like Buddhist and Jaina samgha(s) were led by individuals who were certainly required to have Rajarshi characteristics e.g. Gautam Buddha, Mahavir Jaina, down to Swami Vivekananda, Sri Auroboindo of our times we may recount innumerable such venerable names.

In our contemporary times, the same tradition may be observed. If we take respectable characters and study their biographies closely, we find ample indications of Rajarshi charcateristics. J N Tata (1839 -1904), "the visionary and industrialist, who ushered India into the age of the Industrial Revolution,40, R N Tagore (1861-1941), the Nobel laureate and versatile genius, the poet-singer-composer-painter-litterateur-philosopher and beyond, Acahrya Prafulla Chandra Ray (1861-1944), a remarkable 
educationist turned entrepreneur, Ardeshir Godrej (1868-1936), an entrepreneur having pioneering contributions in the product category of security systems, soaps etc.-- all have displayed the same profound legacy.

M K Gandhi (1869-1948)—anybody who cares to closely examine his classic autobiography gets convinced about his earnest urge and sincere efforts to attain Rishi-hood amidst the turmoil of external socio-political world in which he was so active and contributed so much.

G D Birla (1894-1983), another very respected and pioneering Industrialist of contemporary India 'evolved steadily to a Räjarshi-kingly without and sagely within... ${ }^{41}$.

Netaji Subhas Chandra Bose (b.1897), the great patriotic hero with 'national and spiritual aspirations ${ }^{42}$ going beyond 'worldly prudence', a man of principles having administrative courage, calmness and fortitude ${ }^{43}$, had a great affinity towards the Rajarshi characteristics from his childhood days.

JRD Tata (1904-1993), arguably the greatest Indian Industrialist in the post-independence era, recipient of the highest civilian award of India i.e. Bharat Ratna, was a man of 'inward autonomy' in full consonance with the 'Spirit of Bharatvarsha' .

A P J Abdul Kalam (1931-2015), a Bharat Ratna, who rose from obscurity to be arguably the most popular president of India, had 'maintained the ascetic rigour of his personal life, working 18 hours a day and practising the veen $\vec{a}$, Kalam, the well-known scientist and the Missile Man of India, displays substantial Rishi qualities apart from the very dynamic Raja characteristics of his life and contributions.

Apart from the very few illustrations of illustrious Rajarshi characters, mentioned above, in the long Indian history of about ten thousand years, there have been innumerable others in all walks of life in all ages who imbibed and displayed such characteristics to various degrees of perfection. Beyond them, we have the realized souls, the divine incarnations, the mystics, who have been the spiritual leaders, showing the humanity the right direction to live a purposeful life. Swami Vivekananda asserts _ '...I challenge anybody to show one single period of her national life when India was lacking in spiritual giants capable of moving the world... ${ }^{44}$

Thus the above panorama of illustrations of Rajjarshi leadership in action from the deep antiquity of Vedic days till today, shows a remarkable continuity of the ideal:

1) Continuity over time (Janaka to Kalam) 
2) Continuity over space (leaders across India)

3) Continuity over gender (both male and female leaders)

4) Continuity over sector (examples from industry, politics, social sector etc.) i.e. the model is comprehensively applicable and eternal in at least Indian context.

\section{The Great Expectations}

Bharatvarsha, i.e. India, one of the most ancient civilisations of the world (according to some 'the cradle of civilisation'45 that is still continuing $^{46} \quad$ albeit in a distorted form, has lived not for herself, but for the whole world. The central theme of her sacred spiritual culture has been 'giving', not 'grabbing'. Thus Swami Vivekananda asserts-'The debt which the world owes to our Motherland is immense. Taking country with country, there is not one race on this earth to which the world owes so much... Here activity prevailed when even Greece did not exist, when Rome was not thought of...Even earlier when history has no record...even from then till now, ideas after ideas have marched out from her, but every word has been spoken with a blessing behind it and peace before it'. ${ }^{47}$

Keeping the aforesaid great contribution in mind, the world therefore looks up to India with fervent expectations. Several well-meaning thinkers have pointed it out in their own inimitable ways:

'The eyes of the whole world are now turned towards this land of India for spiritual food; and India has to provide it for all the races. Here alone is the best ideal for mankind; and Western scholars are now striving to understand this ideal which is enshrined in our Sanskrit literature and philosophy, and which has been the characteristic of India all through the ages. ${ }^{48}$ - Swami Vivekananda

'There is nothing in science or science fiction that the Hindu mind has not already thought about. The main difference is that Hindu Yogis controlled the forces of nature through the power of their minds and not through technology, which is a much more dangerous way to harness these forces....Hinduism can help spiritualize the ecology movement. ${ }^{\text {,9 }}$ —David Frawley 
'And above all, what India has to give to the world is this... "Ekam sat, viprah vahudha vadanti"-That which exists is One; sages call It by various names ${ }^{50}$ —Swami Vivekananda

* 'Up, India, and conquer the world with your spirituality. ${ }^{51}$ - Swami Vivekananda

* 'There have been periods of decay and degradation. I do no attach much importance to them; we all know that. Such periods have been necessary. A mighty tree produces a beautiful ripe fruit. That fruit falls on the ground, it decays and rots, and out of that decay springs the root and the future tree, perhaps mightier than the first one. This period of decay through which we have passed was all the more necessary. Out of this decay is coming the India of the future; it is sprouting, it's first leaves are already out; and a mighty, gigantic tree, the Urddhvamula,(Referring to BG,15.1) is here, already beginning to appear;... ${ }^{52}-$ Swami Vivekananda

* 'The solution is not by bringing down the higher, but by raising the lower up to the level of the higher. ${ }^{, 53}$ - Swami Vivekanada

The world expects India to translate the Vedantic teachings to reality. Following assertions of Swami Vivekananda point to that:

- 'Strength, strength is what the Upanishads speak to me from every page. ${ }^{54}$

- 'Freedom, physical freedom, mental freedom, and spiritual freedom are the watchwords of the Upanishads...this is the one scripture in the world, of all others, that does not talk of salvation, bit of freedom. ${ }^{, 55}$

- 'The...great idea which the world is waiting to receive from our Upanishads is the solidarity of this universe. ${ }^{56}$

'...here in India the first and the foremost duty of our lives is to be spiritual first... National union in India must 
be a gathering up of its scattered spiritual forces. A nation in India must be a union of those whose hearts beat to the same spiritual tune. ${ }^{57}$

'...there is no regeneration for India until you be spiritual...another great lesson we have to remember; imitation is not civilization. ${ }^{58}$

'...India still keeps alive the inner principle of her own civilization against the cyclonic fury of contradictions...This has been the great function of the Brahmins of this land, to keep the lamp lighted when the storm has been raging on all sides. ${ }^{59}$ - Rabindranath Tagore

We in the East, however poor we may be materially, must reserve the right of judging what we consider to be beneficial or not for humanity, of our civilization. By exercising this right of judgment we shall not only be serving our own country, but do our inescapable duty to the whole world... ${ }^{60}-$ Rabindranath Tagore

'... in the West we have built a large, beautiful ship. It has all the comforts in it, but one thing is missing: it has no compass and does not know where to go. Men like Tagore and Gandhi and their spiritual forebears had found the compass. Why can this compass not be put in the human ship so that both can realize their purpose? ${ }^{\text {61 }}$ -Werner Heisenberg to Albert Einstein

'A state of things must be brought about in which mutual toleration is the law, an order in which many elements, racial, national, cultural, spiritual can exist side by side and form a multiple unity;... That would be a true state of perfectly developed human civilization, a true basis for the higher progress of the race. In this new order India with her spiritual culture turned towards the highest aims of humanity would find her rightful place and would become one of the leaders of the human evolution by the greatness of her ideals and the capacity of her peoples for the spiritualization of life. ${ }^{62}$ - Sri Aurobindo 


\section{Rajjarshi for the World}

To live up to the expectations India must get connected to her cultural roots and draw strength from there. Many world thinkers have argued that a rejuvenated India firmly rooted to her spiritual heritage can save the humanity from the impending danger.

Thus, for example, the famous sociologist Sorokin argues:

'...a vast body of...evidence proves (1) that with an increase in education, scientific discoveries and inventions, crime has not decreased; that comparatively illiterate persons, nations and groups are not more criminal than literate ones; and that criminals are no less intelligent(in terms of schooling and mental tests) than non-criminals;(2) that there is a very remote relationship, if any, between education, I.Q., school grades and other forms of measured intelligence, on the one hand and egoism or altruism and antisocial or co-operative traits, on the other;(3) that even the intellectual elite of the past four centuries distinguished for their genius, have hardly been ethically superior to the rank and file. The widely accepted opinion that science, technology and education invariably exert only moral, pacific, and socially ennobling effects is a sheer myth. ${ }^{, 63}$

* 'A considerable part of the ethical norms of various hedonistic, materialistic ad utilitarian ethical systems, based on the principle of the struggle of existence... have recommended and inspired the most selfish, antisocial, and destructive forms of conduct and relationships. As such they have been not inhibitors of war but direct instigators of interpersonal and intergroup conflicts. ${ }^{, 64}$

* '...the great ascetics and hermits, true religious leaders, and mystics perform the functions of highest altruism through striving to achieve a union with God or the Absolute...The goal of union with the Absolute already contains within itself as the first step, unlimited love for man and the entire world...the highest altruism and the highest creativity are inseparable...only a cooperative organization free from every competitive elements, with the widest scope for its altruism, and exhibiting the most intense, the purest, and the wisest forms of love, represents the highest altruistic type. Its end is altruism itself. ${ }^{, 65}$

Thus we infer that the solution to the wars, conflicts and general disorder doesn't lie on the form of the government so much, as it is in the mental constitution of the people, because they germinate in the mind first 
and then manifest outside. Hence the control of the mind through Rishi dimensions seems to be a better remedy; therefore what is required is the internal unification of the mankind, a unity at the subtle level is the need of the hour as indicated by Sri Aurobindo.

Such a grand unity transcending all diversities, can be achieved through authentic spirituality as emphasized by Sri Aurobindo-'while it is possible to construct a precarious and quite mechanical unity by political and administrative means, the unity of the human race, even if achieved, can only be secured and can only be made real if the religion of humanity, which is at present the highest active ideal of mankind, spiritualises itself and becomes the general inner law of human life. ${ }^{, 66}$

Realising such an inner law 'our forefathers did spread a single pure white carpet whereon all the world was cordially invited to take its seat in amity and good fellowship. No quarrel could have arisen there; for $\mathrm{He}$, in whose name the invitation went forth, for all time to come, was Santam, Sivam, Advaitam - the Peaceful, in the heart of all conflicts; the Good, who is revealed through all losses and sufferings; the One, in all diversities of creation. And in His name was this eternal truth declared in ancient India: "He alone sees, who sees all beings as himself"( ätmabat sarvabbuteshu, ya passhyati, sa pashyati) ${ }^{67}$

Such an all-embracing invitation must again emanate from a resurgent India led by such Rajarshi leaders. Only then the 'evolutionary failure' may be averted and probably that is the destiny as pointed out by the great historian Arnold Toynbee--'...it is already becoming clear that a chapter which had a Western beginning will have to have an Indian ending...The survival of the human race is at stake...The primary reason is that this teaching is right — and is right because it flows from a true vision of spiritual reality. ${ }^{68}$

\section{References}

1. In the OECD report titled World Economy, we find our Bhäratvarsha stood first for almost 17 centuries (from $0 \mathrm{AD}$ to $1700 \mathrm{AD}$ roughly) in per capita GDP as well as in contribution to world GDP; World Economy (2007); Organisation for Economic Cooperation and Development(OECD), Appendix

2. We get mention of this Rajjarshi paramparä in many ancient texts e.g. shloka(s) $4.1 \& 2$ of Srimad Bhagavad Gita (BG); Chapter 7 of Book I of Kautilya's Arthashastra, particularly verses 1.7.1-8;Mahabharata-Virat Parva,65.14; In the 
famous history based epic-poem Raghubamsam of Kalidāsa, of the twenty-nine kings all were trying to follow this ideal excepting one and the fall-out in either case has been depicted in graphic detail to establish the importance of Rājarshi leadership

3. Chandogya Upanishad, 5.3, 5.11

4. Aurobindo, Sri; The Ideal of The Karmayogin; Sri Aurobindo Ashram(2007),p.17

5. Kautilya's Arthashastra ; verse- no. 7.5.19-26

6. Rangarajan L N; Kautilya's Arthashastra; Penguin Publication(1990),verse7.5.28,p.159

7. Ibid., verses- 1.7.1-8,p.145

8. Einstein, Albert; Ideas \& Opinions; Rupa \& Co.(2009),p.53

9. quoted in Chakraborty, S K \& Chakraborty, D; Human Values \& Ethics: In Search of Organisational Integrity; Himalaya Publishing House,(2014),p.7

10. Vivekananda, Swami; Complete Works of Swami Vivekananda(CWSV), Advaita Ashrama,Kolkata,2009,vol.2,p.306

11. quoted: Chakraborty, S K \& Chakraborty, D; Spirituality in Management: Means or End?,New Delhi, Oxford University Press (2008),p.41

12. Kautilya's Arthashastra, Ch VII, Book 1

13. Manusmriti Chapter vii, verses- 5,6,7; F. Max Muller(ed.); Manusmriti, The Sacred Books of the East; Motilal Banarsidass(1886);vol.25,p.216

14. Ibid.,p.221

15. Ibid.,pp.222-223

16. a sattwa guna: Srimad Bhagavad Gita(BG);verse-14.11

17. Ramayana of Valmiki; Ayodhyakanda,12.61,111.30

18. Ibid.,2.112.21-25

19. Tagore, Rabindranath; Rabindra Rachanabali (Works of Tagore in Bengali),vol.11, Govt. of West Bengal(1368 Bengali calendar),prabandha,p.679680

20. Mahabharata of Vyasa; Bhattacharya, Haridas Siddhanta Vagish, Mahabharatam (Bengali/Sanskrit) (43 volumes),Viswabani Prakashani,1389(Bengali Era) Adiparva, verse-150.5

21. Ibid.,Sabhaprava,verses-34.2-33

22. Ibid.,Vanaparabva,verses-32.24-39

23. Ibid.,Bhismaparva,verses-13.100-103

24. Ibid.,Viratparva,verse-65.14), etc.

25. Mandukya Upanishad,verse-2

26. Chandogya Upanishad, verse-5.3.1

27. BrihadAranyaka Upanishad, verse-3.6.1

28. Mukherjee, Radha Kumud; Chandragupta Maurya and His Times(4th ed.),Motilal Banarsidass(1988);p.9

29. Chakraborty, S K \& Chakraborty D; Rajarshi Leadership; Sri Aurobindo Society, Pondicherry(2014);p.268

30. quoted in: ibid.,p,.45 
31. Mukherjee, Radha Kumud; Ashoka; Motilal Banarsidass(1989);p.20-32

32. 'There are in all one hundred and twelve places in the text (i.e. Arthashastra by Kautilya) where a number of earlier authorities and opinions held by them are mentioned'- Kautilya's Arthashastra;op.cit.,Introduction,p.16

33. quoted in : Rajarshi Leadership; op.cit.,p.279

34. Raghuvamsam of Kalidasa; verse-VI.76

35. Sarkar, B K; The Positive Background of Hindu Sociology; Motilal Banarsidass(1985); p.15

36. K A Nilakanta Shastri; History of South India from Prebistoric times to fall of Vijaynagar, Oxford University Press (reprinted 2002); p.151

37. Majumdar, R C; The History \& Culture of the Indian People; Bharatiya Vidya Bhavan (2006), Vol.6,pp.322-23

38. Sarkar, Jadunath; Shivaji \& His Times(2ed); Longman, Greens \& Co.,(1920); p.26

39. Rajarshi Leadership; op.cit.,pp.286-289

40. Lala, R M; Beyond The Last Blue Mountain-A Life of J R D Tata; Penguin Books Ltd.(1993); p.4

41. Jitatmananda, Swami; quoted in: Jotwani Naresh, Conqueror of the Self $-G D$ Birla; Bharatiya Vidya Bhavan(1998); Benediction

42. Bose, Subhas Chandra; An Indian Pilgrim; p.132; www.hindustanbooks.com

43. ibid.,p.134

44. Vivekananda, Swami; Complete Works of Swami Vivekananda, Advaita Ashrama (1964);vol.4, p.315

45. Frawley, David et.al.; In Search of the Cradle of Civilisation: New Light on Ancient India; Quest Books(2001)

46. Durant, Will; The Story of Civilisation / Our Oriental Heritage; Simon \& Schuster(2011);p.521

47. Vivekananda, Swami; Complete Works of Swami Vivekananda(CWSV); Advaita Ashram(2009);vol.3,p.107

48. Vivekananda, Swami; CWSV, op.cit.,vol.3,p.138

49. Frawley, David; How I Became a Hindu; Voice of India(2000); pp.173-176

50. Vivekananda, Swami; Lectures from Colombo to Almora (LCA); Advaita Ashrama(1990);pp.12-13

51. Ibid., p.203

52. Ibid.,p. 214

53. Ibid.,p.224

54. Ibid.,p.156

55. Ibid.,p.158

56. Ibid.,p. 217

57. Ibid.,p.314

58. Ibid.,p.324-325

59. Tagore, Rabindranath; The English Writings of Rabindranath Tagore(EWRT); Sahitya Akademi (2008); vol.3,p.457 
60. Ibid.,vol.3,p.949,1932

61. quoted in: Kalam, A P J; Ignited Minds; Viking;p.76

62. Aurobindo, Sri; The Human Cycle/The Ideal of Human Unity/War and SelfDetermination; Sri Aurobindo Ashram(2012); Appendix I

63. Sorokin, Pitirim A; The Reconstruction of Humanity; Bharatiya Vidya Bhavan(1960); pp.45-46

64. Ibid.,p.50

65. ibid.,pp-66-68

66. Aurobindo, Sri; The Ideal of Human Unity in The Human Cycle/The Ideal of Human Unity/War and Self-Determination; Sri Aurobindo Ashram(2012);p.571

67. Tagore, Rabindranath; The English Writings of Rabindranath Tagore(EWRT); Sahitya Akademi (2008); vol.3,p.491

68. Toynbee, Arnold; Sri Ramakrishna and His Unique Message; Advaita Ashrama; Foreword, pp. viii-ix 